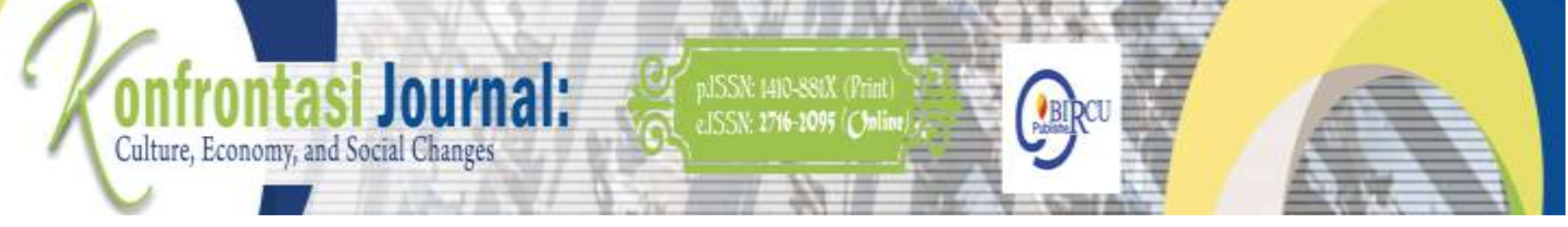

\title{
Women Journalist in the Middle of Taliban Power
}

\author{
M. Yoserizal Saragih \\ Universitas Islam Negeri Sumatera Utara, Indonesia \\ yosesaragih77@gmail.com
}

\begin{abstract}
This article reviews women journalists in the midst of Taliban rule which is being highly discussed in various worlds today. The purpose of this paper is to increase knowledge about what is happening at this time. This paper is a descriptive analysis that aims to describe, inventory, and analyze the conditions being investigated in a systematic, factual and accurate manner, then from the results of the analysis a conclusion can be drawn. The results of the discussion show that after the Taliban succeeded in taking power on August 15, 2021Taliban will respect women's rights, but these rights must be within the limits of Islamic sharia law, women can study and work, women can join the government, Urqa is no longer required as well as women's rights are fulfilled. However, behind the Taliban's power, female journalists in Afghanistan have their own challenges because their rights as women in that country are limited. Since the transfer of power, women journalists in Afghanistan have been threatened, as has been reported in various media.
\end{abstract}

Keywords women journalists; Taliban; power

\section{Introduction}

The Taliban is a santri group, labeled as a fundamentalist Islamist movement operating in Afghanistan with roots in neighboring Afghanistan. The Taliban ruled Afghanistan officially from 1996 to 2001 after toppling the US-backed Mujahideen government. The Taliban government was officially overthrown in 2001 by a US military invasion. But the reality is this group is now rising and controlling most of Afghanistan. The official government, practically only has limited power in the capital city of Kabul and its surroundings. The Taliban is also a movement that began to show its existence in the 1990s in several Islamic boarding schools that are indeed Sunni. Initially, the Taliban was dominated by ethnic Pashtu's residing in Southern Afghanistan.

According to information in an article written by Felix Kuehn with the title Taliban History of War and Peace in Afghanistan, it is known that the Taliban became stronger after officially overthrowing the Afghan capital, Kabul in 1996. This movement then further strengthens existing instruments, such as the ability to fight, increase finances or income and the ability to negotiate. Not only Kabul, the Taliban also managed to reach other cities tens of kilometers from Kabul and formed a committee or department. Although the committee's performance was considered very poor, its initial formation was focused on international diplomacy activities and providing a sense of comfort and justice for the Taliban themselves.

The prestige of the Taliban faded in 2001, when the United States (US) army invaded Afghanistan. The defeat of the Taliban from the US army is really hitting. The US came with all the capable military facilities, making the Taliban in turmoil. In addition, the Taliban also began to lack sympathy from some of its supporters. Even though it has been overthrown 20 years, the Taliban still shows their existence and resistance. Until finally on Sunday, August 15, 2021, the Taliban succeeded in occupying the presidential palace in Kabul and taking control of it. 
Konfrontasi Journal: Culture, Economy and Social Changes, 8 (3) September 2021, 142-151

ISSN: 1410-881X (Print), 2716-2095 (Online)

M. Yoserizal Saragih: Women Journalist in the Middle of Taliban Power

DOI: https://doi.org/10.33258/konfrontasi2.v8i3.152

http://www.konfrontasi.net/index.php/konfrontasi2

The Taliban's brief return to power in Afghanistan after two decades has left neighboring Afghanistan scrambling to find ways to adjust to changing geopolitical views. Many are in geopolitical turmoil right now, as neighboring Afghanistan looks for ways to adjust to the emerging Taliban regime.

President Joe Biden in April ordered the Pentagon to withdraw US troops from Afghanistan on September 11, effectively ending America's longest war. As the United States' military presence dwindled, the Taliban made rapid advances on the battlefield despite still being outnumbered by the Afghan military. In recent weeks, the group has seized major cities and provincial capitals before entering the capital Kabul on Sunday 22 August 2021 and taking control of the presidential palace.

Based on several reports in various media, now the Taliban has succeeded in controlling Afghanistan in August 2021. Including the media for CNBC Indonesia, CNN Indonesia, Compas.com, TV One, and others. In several reports in various media, there was some speculation that there were concerns about the power of the Taliban. As expressed by Leni Winarni, she also expressed her concern for Afghanistan if the government was held by the Taliban.

The power currently held by the Taliban, makes female journalists in Afghanistan feel worried because the movement of female journalists is restricted, as reported in Detik News.com media stating that Taliban Takes Power, Afghan Woman Journalist Says Banned From Work. In addition, CNN Indonesia press media also said that the female journalist fled after the interview with the Taliban spokesman. In Media TV One News also said that the Taliban was a threat to women, and the Taliban also broke promises, a number of female journalists were banned from work.

A female journalist, Clarissa Ward, stated that her presence at the presidential palace made the atmosphere tense, my presence there immediately created tension, they told me to stand aside because I am a woman. Ward also said that the fall of the Afghan government has caused Afghan women not to dare to leave their homes. Many Afghan women feared for their lives when the Taliban came to power. This also applies to female journalists living in Kabul. They fear that the Taliban will retaliate against the media coverage.

Based on the explanation above, therefore, the author wants to study or write an article in the form of a scientific work with the title Women Journalists amid Taliban Power.

\section{Review of Literature}

\subsection{Female Journalists}

Mass media is a tool used in conveying the message from the source to the audience by using mechanical means of communication, such as newspapers, radio, television and etc. In this case, here the mass media is print media or newspapers. (Saragih, 2018).

Journalist is a person whose job is to find and compile news to be published in newspapers, magazines, radio, and television. While women is a term used for humans who are gender or female. So, female journalists are people whose jobs are to find and compile news to be published in newspapers, magazines, radio, and television with a female gender.

Literally, the word journalism means journalism or matters related to reporting. The word journalism (journalistic) comes from the root word "journal" which means report or record. The word Journal itself comes from the word "du Jour" (ancient Greek), which means "day" or diary. In French "jour" means "day" or diary. Curtis D. Mac Douggall, in his book entitled "Interpretative Reporting" states that what is meant by journalism is the activity of gathering news, finding facts, and reporting events. Journalism is a profession. Called a profession because it has four characteristics, namely: 
a. have the freedom to do work

b. based on vocation and attachment to work,

c. expertise is required, and

d. Responsible and bound to the work code of ethics.

Basically the world of the press, from birth until now has demanded certain competencies for journalists. A journalist is required to be professional in carrying out their duties. However, until now, the definition of professionalism is still unclear. However, there are several moral bases that attribute professionalism to journalists, including:

a. Autonomy means freedom to exercise self-determination and the development of a selfregulating organization.

b. Commitment that focuses on service not on personal economic gain.

c. Expertise is performing a unique and essential service. Not heavy on intellectual technique, long period of specialized training in order to acquire systematic knowledge based on research.

d. Responsibility, namely the ability to fulfill obligations or act without guidance from above, the creation and application of a code of ethics.

The moral attribute is a basic obligation that journalists must have. In this way, when the basic spirit of journalists has been properly embedded, it is hoped that the future of the Indonesian press will be more advanced. But the moral aspect alone is not enough, journalists must also have intellectual skills. In this way, the two elements can complement each other. James Reston, chairman of The New York Times office (at the time) in Washington, said that the main job of a journalist is not the owner of the press company, or the editors, or the country or those who provide the news. So that researchers can conclude that a journalist must be neutral without getting influenced by anyone in writing news for the public. A journalist must also cover all aspects of every issue and will not cover what he does not know.

So what is the relationship between journalists and women today? The author sees that gender equality is still not applied in all aspects of life, especially in work. Whereas a Mahatma Gandhi said that women are human beings equal to men and are filled with the same desire to achieve freedom.

\subsection{Taliban rule}

Power is the authority obtained by a person or group to exercise the authority in accordance with the authority given, the authority may not be exercised beyond the authority obtained or the ability of a person or group to influence the behavior of other people or groups in accordance with the wishes of the perpetrator or power is the ability to influence other parties to think and behave in accordance with the will of the influencing party.

In general, power can mean class power, king power, state official power. So it is not wrong to say that power is the ability to influence other parties according to the will of the holder of that power. Robert Mac Ever said that power is the ability to control the behavior of others either directly by giving orders / indirectly by using all available tools and means. Power is usually in the form of relationships, some are ruled and some are ruled. Humans act as subjects as well as objects of power.

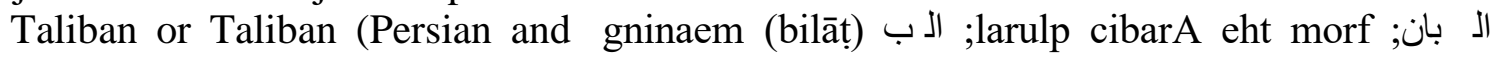
disciple), whose members refer to the organization officially as the Islamic Emirate of Afghanistan, is a Pashtun-supported Deobandi Islamic nationalist movement that effectively controlled almost all of Afghanistan from 1996 to 2001 and returned to control of Afghanistan in 2021. Currently, the Taliban are one of two political entities that both claim to 
be the legitimate government of Afghanistan as well as the Republican side. Several countries and international organizations branded this movement as a terrorist organization.

Based on the above understanding, the power of the Taliban is an authority that is obtained by a group of organizations whose members are officially the Islamic Emirate of Afghanistan or an Islamic nationalist movement.

\subsection{News Media}

News media refers to the part of mass media that focuses on presenting the latest news to the public, including print media (newspapers, magazines); broadcast media (radio stations, television stations, television networks), and internet-based media (websites, blogs). In the media reporting guidelines, freedom of opinion, freedom of expression, and freedom of the press are human rights protected by Pancasila, the 1945 Constitution, and the United Nations Universal Declaration of Human Rights. The existence of the media is also a part of freedom of opinion, freedom of expression, and freedom of the press.

News in the constructionist view is the result of social construction that involves the intervention of ideology, values from journalists or the media. News construction begins with the selection of facts, the determination of the news value, which is contained in the course of a news story. This fact-choosing process is based on the assumption that it is impossible for journalists to see events without perspective. In choosing facts, there are two possibilities, namely what is selected (included) and what is discarded (excluded). In the selected option (included), the emphasis on certain aspects is done by choosing angels, certain facts and forgetting other aspects. Consequently, the understanding and construction of an event may differ from one medium to another.

News is basically formed through the process of news organization. Complex and irregular events are made neater by organization. Organizing news involves two elements, namely journalists and editors. Then the results of the editor which are summarized by journalists and journalists covered from the field will be included in the news media which will be disseminated to the public, such media as print media (newspapers, magazines); broadcast media (radio stations, television stations, television networks), and internet-based media (websites, blogs)

\section{Research Methods}

The research method in this study is an analytical study with a descriptive qualitative approach, namely research that examines data in depth about all the complexities that exist in research and produces descriptive data in the form of written or spoken words. In this case, the researcher acts as a facilitator who participates in giving critical meaning to the reality constructed by the research subject. This research is also included in library research, namely research on news coverage in the media. This research is also subjective-constructivist in which reality is the result of mental construction of individual social actors, so that reality is understood in various ways and is influenced by experience, context, and time. Through this research, the author examines, examines, and analyzes everything that is the subject of research to reach a conclusion. 


\section{Discussion}

\subsection{Reporting by Women Journalists in the Middle of Taliban Power}

Based on the description above, it can be concluded that journalism is not only recording, conveying and disseminating information, but rather the art or skill of delivering news. The role of Islamic journalism in convincing the public to report the Hajj in 2021 amidst Covid-19, Islamic journalism is known asas educators (muaddib), straighteners of information (musaddid), reformers (mujaddid), unifiers (muwahid), and fighters(mujahid). To carry out this role, Islamic journalism has the characteristic that every information in a news report must be owned by the Prophet, such as:shidiq (truth), amanah (trusted), tabligh (deliver), and fathonah (intelligent).

In addition, journalism also has other roles, namely, as a reform agent, entertainment provider, social control tool, public educator, information provider, broadening the horizons of thought, focusing attention, fostering aspirations, creating a constructive atmosphere, as a bridge, being able to recognize social norms, able to grow appetite, as well asable to change a weak attitude into a stronger attitude. A journalist is a person who covers an event or a person whose job is to find and compile news to be published in the press or mass media. As we know, lately various media are hotly reporting about the power taken over by the Taliban. The transfer of power has made women journalists in Afghanistan threatened. Like several press media that reported that female journalists in Afghanistan were prohibited from working, this statement was reported on Detik News.com stating that the Taliban was in power, Afghan female journalists claimed to be banned from working. In addition, CNN Indonesia press media also said that the female journalist fled after the interview with the Taliban spokesman. In Media TV One News also said that the Taliban was a threat to women, and the Taliban also broke promises, a number of female journalists were banned from work. In addition, the media sembinews.com also mentioned that female journalists working on the Afghan news agency were sent home, the regime had changed. Serambinews.com Kabul said that an Afghan female journalist said the Taliban refused to let her work. Several reports of female journalists in the midst of Taliban rule are now in the spotlight. As shown in the following image:

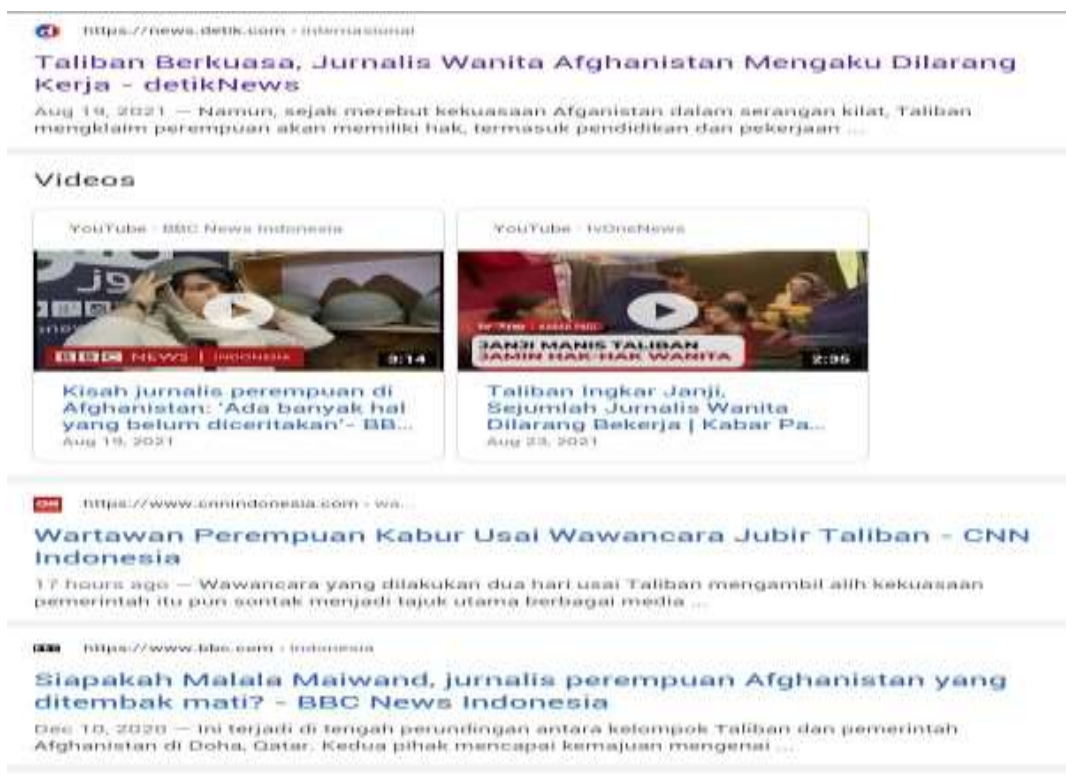


Based on the news above, female journalists in the midst of Taliban rule, according to Taliban spokesman Zabihullah Mujahid, said that the Taliban would guarantee women's rights in Afghanistan, including being allowed to work and get higher education. However, it did not last long that promise was tarnished by a number of incidents.

The Taliban gave assurances that they were trying to make Afghanistan a peaceful country and not associated with acts of terrorism. In addition, the Taliban promised the rights of life for women, because women are an important part of Afghan society and guarantee all their rights within the limits of Islamic teachings.

Based on this, the transfer of power that was taken over by the Taliban is now experiencing social changes in the order of life in Afghanistan, based on the various reports above that the tarnished rights of life for women to work and higher education show one of the social changes in the country.

\subsection{Theory of Social Change amid the Power of the Taliban}

Social change is a process of shifting the structure or order in society, which includes a more innovative mindset, attitude, and social life to get a more dignified life. The figures who talk about social change are: Kingsley Davis, Mac Iver, Selo Soemarjan, William Ogburn. The tendency for social changes to occur is a natural symptom that arises from the association of human life in society. Social changes will continue as long as there is interaction between humans and between communities. Social change occurs because of changes in the elements that maintain the balance of society. Social changes in society should not be seen from one side only, because these changes can result in shifts in many sectors of social society. This means, social change will always occur in every part of society itself. Symptoms of social change in society can be seen from changes in the value system and norms that apply at that time and which no longer apply in society. Of course, this social change occurs not only because individuals in the community want to change, but because of changes in various forms of government power.

Based on the theory of social change, female journalists in Afghanistan who are prohibited from working in the midst of the Taliban rule are one of the factors of social change as a result of the conflict/war in the country. In conflict theory, social change is influenced by the views of several experts such as Karl Max and Ralf Dahrendorf. In this theory of social change, of course, views conflict as a source of social change in society. This theory sees society in two groups or classes that are in conflict with each other, namely the bourgeoisie and the proletariat. These two social groups in society can be considered as employers and assistants. With more ownership of property and rights to life by the bourgeoisie and less for the proletariat, it will trigger conflict in society, resulting in a social revolution that results in social change. Likewise, the existing conflict between the Taliban and Afghanistan which has now been successfully taken over by the Taliban has resulted in social change.

The continuous conflict between these two groups will bring society into social change. Sooner or later, big or small the size or scale of the social changes that occur. Thus, the group that wins or succeeds in conflict according to this theory is the group that has the authority or authority to control or suppress others so that community stability can work. Social changes that occur in Afghanistan, such as the loss of women's rights in Afghanistan, the prohibition of work and higher education in the midst of Taliban rule, is a form of social change. 


\subsection{Afghan women's rights in the midst of Taliban rule}

Since the Taliban took control of the Afghan capital, women will be given rights in employment and other activities. Women have the right to education and jobs, but what life will be like under Taliban rule remains unclear. Many Afghan women have expressed fear of a return to the repressive rule of law that the previous Taliban administration had imposed.

Various international organizations have also expressed similar concerns. According to women's rights activist Hoda Raha stated that The Taliban have snatched away every hope of Afghan women. Contrary to the statement of the Taliban spokesman Zabihullah Mujahid said that the Taliban would guarantee women's rights in Afghanistan including being allowed to work and get higher education, and support women's rights under sharia law.

The statement sparked further questions, including how much the Taliban's views on women's rights have changed since the group was ousted 20 years ago. Taliban political spokesman Shail Saheen said that the Taliban respects women's rights including not being obliged to use the Buqa. Taliban said they wanted peaceful relations with other countries and would respect the rights of Afghan women within the framework of Islamic law.

Since taking overAfghanistan on August 15, 2021 a Taliban spokesman said women would be free to work but gave few details about other rules and restrictions, as Afghans must live within the framework of Islam. The Taliban introduced or supported punishment according to their strict interpretation of the Islamic legal system, Sharia law, when they controlled Afghanistan between 1996 and 2001. At that time, women had to wear the allcovering burqa, and the Taliban also disapproved of girls aged 10 years and older. over going to school. However, in this takeover of power, the Taliban took a different approach. Here are some of the promises made to Afghans, especially women's rights:

a. Women can study and work

b. Women can join the government

c. Burqa is no longer mandatory

d. Guaranteed women's rights are fulfilled

Based on these promises, some people are still responding with concern, because there are some opponents of the Taliban who think that the promises are just a trick. However, as a country including Indonesia, we hope that Afghan women have their rights respected. Indonesia also continues to have a commitment to help create peace, especially cooperation in empowering women.

\subsection{Female Journalists amid Taliban Power}

Journalist or also known as journalist is a term for someone who carries out journalistic activities such as writing, analyzing, and reporting an event to the public through the mass media on a regular basis. Journalistic activities are carried out in various mass media such as newspapers, magazines, radio, television, as well as online media. Journalists are often considered as representatives of the community's voice regarding various events that exist and occur in society.

However, behind the Taliban's rule, female journalists in Afghanistan face challenges because their rights as women in the country are limited. Since the transfer of power, women journalists in Afghanistan have been threatened. Like several press media who reported that female journalists in Afghanistan were prohibited from working in this settlement, as reported by Detik News.com, stated that Taliban Takes Power, Afghan Woman Journalist Says Banned From Work. In addition, CNN Indonesia press media also said that the female journalist fled after the interview with the Taliban spokesman. In Media TvOneNews also said that the Taliban was a threat to women, and the Taliban also broke promises, a number of female journalists were banned from work. In addition, the media sembinews.com also 
mentioned that female journalists working on the Afghan news agency were sent home, the regime had changed. Serambinews.com Kabul said that an Afghan female journalist said the Taliban refused to let her work.

An Afghan woman journalist admits she was barred from working at her TV station after the Taliban took control of her country. A woman journalist revealed that she had to hide from the Taliban when Afghanistan began to be controlled by the group. Arghand says on CNN Business via WhatsApp and shared his experiences over the past two weeks. That in the end, he left the country because, like millions of people, he feared the Taliban. And Saad Mohseni, owner of TOLONews, also said the Arghand case was symbolic of the situation in Afghanistan.

The fall of the previous Taliban regime in 2001 has opened a new era of media freedom across Afghanistan. TOLO News has been employing female presenters and journalists, while the fundamentalist group the Taliban banned women from working and forbade girls from going to school when they were in power from 1996 to 2001 . However, in the new power of the Taliban said they would respect women's rights, but those rights had to be within the limits of sharia law.

\section{Conclusion}

The Taliban is one of two political entities that both claim to be the legitimate government of Afghanistan as well as the Republican side. Taliban tooare the santri, who are labeled as fundamentalist Islamist movements operating in Afghanistan with roots in neighboring Afghanistan. The Taliban ruled Afghanistan officially from 1996 to 2001 after toppling the US-backed Mujahideen government. On 15 August 2021 the Taliban again seized control of Afghanistan. The power currently held by the Taliban, makes female journalists in Afghanistan feel worried because the movement of female journalists is restricted, as reported in the Detik News.com media stating that the Taliban is in power, female Afghan journalists claim to be prohibited from working. In addition, CNN Indonesia press media also said that the female journalist fled after the interview with the Taliban spokesman. In Media TvOneNews also said that the Taliban is a threat to women,

Female journalists are people whose job is to find and compile news to be published in newspapers, magazines, radio, and television with female gender. With the transfer of power into the hands of the Taliban, causing social changes in the country, it can be seen in the media coverage that women are prohibited from working and being educated. However,on the new power the Taliban say will respect women's rights, but these rights must be within the limits of Islamic sharia law.

\section{References}

Ajeng,https://news.okezone.com/read/2021/08/19/18/2457596/sejarah-taliban-dan-awalmerebut-kekuasan-di-afghanistan?page=2, accessed on: August 26, 2021.

Arisnadi, Herman. (2015). Thoughts of Sociological Figures, Yogyakarta: Divapres.

Batamnews.com,https://www.batamnews.co.id/berita-80043-curhatan-jurnalis- Wanita-diafghanistan-saat-taliban-berkuasa-doakan-saya.html?page=3, accessed at: 1 September 2021.

Benedikta, https://www.liputan6.com/global/read/4634917/4-promise-taliban-for-kaumperempuan-after-berhasil-kuasai-afghanistan, accessed on: 1 September 2021.

Clarissa Ward, Female Journalist In Afghanistan, The story of a female journalist covering the streets of Kabul after the Taliban took power, 
https://kumparan.com/kumparanwoman/cepat-jurnalis-perempuan-yang-meliput-

jalanan-kabul-after-taliban-berkuasa-1wNEqL50fn3/3 accessed on: August 31, 2021.

CNNIndonesia,https://www.cnnindonesia.com/internasional/20210830154149-113-

687387/wartawan-perempuan-kabur-usai-interview-jubir-taliban, Accessed on: August 31, 2021.

Currently Listed Entities, Public Safety Canada, Accessed: August 31, 2021.

Damsar. (2015). Introduction to Sociological Theory, Jakarta: Prenadamedia Group.

Deputy Director of Asia Programs at the Woodrow Wilson Center, Michael Kugelman To CNBC International quoted Sunday, August 22, 2021.

detiknews.com,https://news.detik.com/internasional/d-5688852/taliban-berkuasa-jurnalis-

Wanita-afghanistan-mengaku-dilarang-kerja, Accessed On: August 31, 2021. .

detiknews.com,https://news.detik.com/internasional/d-5688852/taliban-berkuasa-jurnalis-

Wanita-afghanistan-mengaku-dilarang-kerja, Accessed On: August 31, 2021.

https://id.wikipedia.org/wiki/Taliban, accessed on: August 31, 2021.

https://www.dw.com/id/taliban/t-37747880, Accessed on: 26 August 2021.

Eriyanto. (2002). Framing Analysis; Construction, Ideology, and Media Politics, Yogyakarta: LKIS.

Gandhi, Mahatma. (2002). Women and Social Injustice, Yogyakarta: The Learning Library. Hamdan Daulay. (2016). Journalism and Press Freedom, Bandung: PT. Rosdakarya Youth.

Hikmat, Mahi M. (2014). Research Methods in the Perspective of Communication and Literature, Yogyakarta: Graha Ilmu.

Joseph, Jani. (2009). To Be A Journalist: Becoming a Professional TV, Radio and Newspaper Journalist, Yogyakarta: Graha Ilmu.

Kriyantono, Rachmat. (2010). Practical Techniques for Communication Research, Jakarta: Kencana Prenada Media Group.

Leni Winarni, Observer of Political Islam Studies and International Conflict Resolution FISIP UNS, accessed on: August 31, 2021.

Miriam Budiardjo. (2008). Fundamentals of Political Science, Jakarta: PT. Gramedia: Main Library.

Nawawi, Hadi. (1991). Social Research Methodology, Yogyakarta: Gajahmada Pers.

Nia Zuriah, Politics and Government, https://zonautara.com/2021/08/21/menlu-berharap-hakhak-perempuan-di-afghanistan-dihonored/, accessed on: 1 September 2021.

Ramlan Surbakti. (1992). Understanding Political Science, Jakarta: PT Gramedia.

This manual was signed by the Press Council and the press community in Jakarta, 3 February 2012, accessed on: 1 September 2021.

Republika.co.id,https://www.republika.co.id/berita/qy4fv2/like-apa-hak-perempuan afghanistan-di- Bawah-Taliban-Latin. Accessed on: September 1, 2021.

Salim, Agus. (2014). Social Change, Yogyakarta: Tiara Wacana.

Saragih, M.,Y. (2018). Some Characteristics of Islamic Journalism Based on Al Quran. Budapest International Research and Critics Institute-Journal (BIRCI-Journal). P. 01-10

Serambinews.com, https://aceh.tribunnews.com/2021/08/20/jurnalis- Wanita-kantor-beritaafghanistan-disuruh-pulang-rezim- already-changed, accessed on: August 31, 2021.

Sudibyo, Agus. (2001). Media Politics and the Battle of Discourse, Yogyakarta: LKIS.

Tempo.com, https://www.tempo.co/abc/6887/taliban-ingin-melindungi-hak-perempuan-diafghanistan-apa-yang-they-meaning, accessed on: 1 September 2021.

Tribunnews.com,https://www.tribunnews.com/internasional/2021/08/18/taliban-promisehonor-hak-hak-perempuan-obligatory-gunakan-jilbab-no-harus-burqa, accessed at: 1 September 2021. 
TvOneNews, https://www.youtube.com/watch?v=bK-mgOt-peg, accessed on: August 31, 2021.

Warta Ekonomi.co.id, https://www.wartaekonomi.co.id/read357684/wartawan- Wanitamelarandiri-dari-afghanistan-usai-interview-dengan-jubir-taliban, accessed on: September 1, 2021. 